\title{
'THIS IS NOT A STORY WHICH WOULD SHOCK!': THE \#METOO CAMPAIGN IN SLOVENIA
}

In post-socialist Slovenia, the \#MeToo campaign (\#jaztudi), which was started by four public intellectuals in 2018, was rather different to its equivalent in most Western counties. The analysis of the \#jaztudi campaign suggests that there are local specifics in the Slovenian material and that the campaign appeared at the peak of the era of neopatriarchy where global inequalities are on the rise. Hundreds of women who testified about sexual harassment and sexual violence were not celebrities and public figures. The men against whom they spoke up were not famous, rich and powerful. They disclosed ordinary, 'small' stories, which were far from spectacular. Women wrote about everyday sexual assaults in childhood, in their teens and in adulthood. The majority of them were not interested in taking legal action against the perpetrators, something which can partially be explained by the contexts of rurality, religious influences and the social norms related to sexual violence towards women that are reproduced in educational, judicial and other social systems. This article provides the social context of the situation facing women in Slovenia and attempts to explain why \#MeToo campaigns in different countries are contextual. It shows the importance of locally specific factors that influence women's readiness to speak out and to denounce perpetrators. A number of factors have a great impact on ending sexual violence against women, including the frequency of violence against women; women's economic and social status; the responses of professionals in public institutions to which women could turn for help; as well as awareness on the part of parents, teachers and communities. The implementation of the Istanbul Convention, which Slovenia ratified in 2015, and its internalisation on both the cognitive and emotional levels, constitute an important historical turning point in the fight to end sexual violence.

Darja Zaviršek - Dr., Prof., Faculty of Social Work, University of Ljubljana, Slovenia. Email: Darja.zavirsek@fsd.uni-lj.si. 
Key words: \#MeToo campaign, sexual violence, post-socialist countries, Slovenia, women's activism

DOI: $10.17323 / 727-0634-2020-18-2-343-356$

In most Western countries, the women who initiated the \#metoo campaign were celebrities, actresses and public figures testifying against famous, rich and powerful men. They revealed 'a pattern of predatory behaviour', to use the phrase coined in the court case against a famous film producer Harvey Weinstein (Pilkington 2020). Over 105 eminent women in the US broke the silence about sexual violence using their real names, not hiding their faces and providing detailed personal stories.

Although the \#metoo campaigns in various contexts are to an extent similar to each other, they are contextually different and depend on the legacies of women's movements, gender awareness imbedded in different societal structures, the economic autonomy of women and the discourse of 'correct family values', to mention just a few factors. As a feminist scholar, activist in the early 1980s women's movement in Yugoslavia and co-founder of a helpline and women's refuge, I have been able to observe that sexual violence against women was discussed much less frequently in this region. Thus, I will analyse specificities of the \#metoo campaign in the case of Slovenia. Methodologically, the analysis of the stories focuses on the contexts within which sexual violence appears rather than the frequencies of different types of assaults or other quantitative indicators.

\section{Contextualising Sexual Violence in the Post-Socialist Space}

In order to contextualise the \#metoo campaign, the state socialist and postsocialist periods need to be briefly addressed. Many scholars have discussed the consequences of state socialism for women, women's movements and rights. Some focus primarily on the fact that women in post-socialist countries were granted some rights by the communist parties (the right to work, divorce and abortion), but that their political mobilisation was introduced top-down. Therefore, compared to Western feminists, women in post-socialist countries developed a different kind of agency and activism (Funk 2014). Others emphasise that prior to 1991, women's movements, although modest in comparison to those in the West, were present and that feminist consciousness developed despite state control (Lukić et al. 2006; Haan at al. 2006; Haan 2016). Most importantly, in socialist states, the issue of violence against women was not openly discussed or actively fought against (Fábián 2010). Despite 'revolutions of intimacy' (Gradskova et al. 2020) during state socialism, there was no safe private sphere for women. Sexual violence against women has remained both a taboo and something that has been normalised in post-socialist countries. Nevertheless, even 
before the collapse of the one-party system, Yugoslav feminists had developed certain tools against gender-based violence such as helplines for women and children victims in Zagreb, Belgrade and Ljubljana ${ }^{1}$.

After 1991, women's rights in fact eroded in most post-socialist countries; Poland with its ultra-conservative anti-abortion legislation is one of the most blatant examples. Conservative political parties and organisations (especially religious ones led and funded by the Catholic and Orthodox churches) systematically violated women's rights as they saw them as a legacy of the communist period which they interpreted as an attack on family values, reproduction and traditionally gendered care work and mothering (Zaviršek, Rajgelj 2018). Almost everything that was considered a 'communist legacy' was deemed harmful for these supposedly renewing societies. A post-socialist femininity was created along the lines of traditionalism; diverse families were stigmatised as hostile to 'true family values' (Zaviršek, Sobočan 2012). Women were asked to once again take their 'proper' place as mothers and carers in the private sphere. Inevitably, this eradicated the public discursive space within which women could discuss all forms of violence against them. Legislation on sexual violence remained based in the concept of force: women had to prove that they actively fought back against the rapist.

On the other hand, on the backdrop of these changes, women's activism against gender-based violence flourished in the 1990s and, under the influence of Western institutions, most post-socialist countries modernised legislation related to violence against women in the private sphere (Fábián 2010). Women established safehouses for victims, helplines and counselling services and worked to empower themselves. At the same time, it became clear that women's resistance was hardly able to compete with the increasingly dominant traditionalism that can be referred to as a neopatriarchy in this context.

Neopatriarchy is not a new concept. Used by Hisham Sharabi (1988) to explain the failed modernisation in Arab societies, and later by Beatrix Campbell (2015) to express how liberal capitalism and patriarchy intertwine, it was defined as a traditionalist response to growing economic inequalities, precariousness and uncertainties that people face in the times of global neoliberal capitalism (Šumi, Zaviršek 2017). Men who lost both their jobs and the traditional role of breadwinners strove to restore their dominant positions. Ultraconservative religious and civil society groups claimed that women were to blame for men's powerlessness. Scapegoating women rendered sexual violence unrecognisable: campaigns against sexual violence were seen as women's attacks on 'traditional' masculinity. The more neoliberalism divided people into minority winners and majority losers, the more traditional discourses against women disciplined them by restoring traditional values and inequalities, laying down restrictions on women's personal choices, notably in reproductive rights.

\footnotetext{
${ }^{1}$ It is important to note, that the first Yugoslav feminist conference took place in Belgrade already in 1978 (Jalušič 2002: 27).
} 
Populist manifestations of neopatriarchy can be seen in anti-abortion campaigners protesting in front of the gynaecological clinics or 'anti-gender' campaigners (Kuhar, Paternotte 2017), as well as the ban of gender and women studies programmes in universities (Report from the Region 2019).

Women's non-governmental organisations were first to raise awareness about different forms of gender-based violence in Slovenia. They demanded state services, such as police, social workers, and health workers, recognise it as a harmful form of violence perpetrated mostly by men and directed against women. Although an SOS helpline for women and children fleeing violence, including sexual violence, was established in 1989, it was not until 1996 that the first safehouse for women and children was opened, Safehouse Maribor. Until the mid-1990s the police and social services were obliged to protect children and mothers from household violence, but not women who were either single or without children (Zaviršek 1997; Robnik 2010). There was a common belief that an adult woman was able to defend herself, and when she was not, it was a sign of her own wrongdoing. Social work was supposed to 'protect the family' but not the right of individual members of the household to live free of violence. Patriarchal gender inequalities were never a topic to be discussed in mainstream social services. Quite the opposite: the widely promoted 'systemic approach' - seen as the cornerstone of modern social work- divided responsibility for violence, either physical or sexual, between two adults equally. In this context, the work of feminist non-governmental organizations pioneered the understanding that sexual violence was part of historic gender inequality.

Slovenia was among many other post-socialist countries which lacked national data on violence against women. A national survey that focused only on incidences of violence against individuals aged over fifteen, appeared in 2010 . $49.3 \%$ of women experienced emotional violence, $23 \%$ physical violence, $14.1 \%$ material violence, $13.9 \%$ restriction of movement, and $6.5 \%$, sexual violence (Leskošek et al. 2010). A smaller study in 2014 at the major gynaecological clinic of the University Medical Centre Ljubljana focused on 1,018 women of reproductive age, who came to the health centre to give birth in the previous three months, covering $80 \%$ of all women who had had a baby in that time period. The average age of the women was nearly thirty-one. Most of them had secondary or higher education; a majority lived with a husband or a partner. Half of them gave birth to their first baby, $40 \%$ to the second. Based on the NorAQ questionnaire, the study showed that every second woman in the sample (46.9\%) reported that they experienced different forms of violence in different periods of their lives. $26.1 \%$ of the women experienced psychological violence, $22.2 \%$ physical violence, and $7.6 \%$ sexual violence. In addition, $16.1 \%$ of women reported different forms of violence by medical personal (Globevnik Velikonja 2018:51).

According to a comparative EU-28 study of gender-based violence against women, the prevalence of sexual harassment after the age of fifteen among all women in Slovenia was 44\% compared to the EU-28 average of 55\% (EU Agency 
for Fundamental Rights 2015: 110). Nearly every second woman experienced sexual harassment after the age of fifteen and $6 \%$ of women in Slovenia experienced sexual violence (compared to 12\% EU-28 average), while $12 \%$ both physical and sexual violence, and $7 \%$ psychological violence at the hands of a family member. $16 \%$ of the respondents experienced physical, sexual or psychological violence before the age of fifteen compared to $35 \%$ EU-28 average (Ibid: 123). No national data is available on child sexual abuse in Slovenia, which may very well contribute to the low awareness of the issue. In striking opposition to these low percentages, Slovenian respondents reported one of the highest shares of cases of stalking for women over fifteen that were reported to the police: $35 \%$ compared to the EU-28 average of $26 \%$ (Ibid: 91). The prevalence of sexual harassment was even higher among women with tertiary education: $67 \%$ compared to the EU-28 (69\%).

The figures reveal similarities with the neighbouring countries of Italy, Croatia and Hungary, where the prevalence of sexual harassment was between 40 $59 \%$, but less so with, for example, France, Germany and the UK, where the prevalence was higher (Ibid: 101). This very likely indicates a lower level of awareness among women in post-socialist countries about the issue, as well as less women-friendly policies and laws concerning sexual assault on women compared to most Western countries. The EU-28 study authors warned that the figures are 'partially dependent on accustomed ways of perceiving, defining and disclosing acts of violence against women, including sexual harassment' (Ibid: 101). In the study that was conducted by WAVE (2014), the situation was similar; in post-socialist countries, Bosnia and Herzegovina, Azerbaijan, Armenia and Bulgaria, less than $11 \%$ of women responded that they experienced sexual abuse, while in Western countries the percentage was much higher, for example 30\% in Austria. The same study showed that in the 'old' EU member states (fifteen countries) there existed 1,338 women's shelters, while in the 'new' EU countries including Cyprus and Malta, there were only 102 shelters (WAVE 2014:24). Hungary, Latvia and Lithuania did not have women's shelters in the time of the WAVE survey.

A society's silence about violence against women inevitably silences the victims. Women rarely report assaults; the perpetrators are seldom charged by law enforcement; courts rarely arrive at substantial sentences. Since 2013, the number of persons who reported sexual assault, which they endured either as children or as adults, to the police in Slovenia has been in decline (Zaviršek 2018). With less than 100 cases of child sexual abuse reported to police in 2014, the situation in Slovenia almost reached the level of 1993, when sexual assault on children and women was deemed non-existent or perceived as an invention of the 'feminists': a word loaded with prejudice (Ibid:250). In such circumstances, the experience of sexual assault becomes the victim's 'personal problem' instead of the result of neopatriarchy. It is relegated to the realm of women's personal tragedy, while perpetrators are rendered anonymous. Disclosing the names of the perpetrators and public discussion of the problem would shift the focus on men. However, in conditions of neopatriarchy, men remain the ones 
who need 'protection': it is they that might lose their jobs due to the \#metoo campaign as they could be falsely accused. Girls and young women still grow up and live in the atmosphere of normalised sexual violence.

Many studies show that different forms of economic inequalities prevent women from disclosing their experiences of sexual assault (Runarsdottir et al. 2019). In Slovenia, the number of women in precarious employment is on the rise; there are fewer women than men in long-term employment; unpaid care work is highly gendered; women experience gender pay gaps and gender pension gaps; young women and women over 55 are disproportionately represented among the unemployed and poor. The gender pay gap has increased from $0.9 \%$ in 2010 to $8 \%$ in 2017, which is the highest increase in the EU-28 and consequently the gender pension gap is $24 \%$ (G.C. 2019). The risk of poverty among women in Slovenia compared to men has been on the rise in the last decade. In 2015, the risk of poverty was $15.6 \%$ for women and $13.0 \%$ for men and in 2018 it was again higher for women (14\%) than men (12.6\%) (Statistical Office of the Republic of Slovenia 2020). The Global Gender Gap Index 2020 shows that the situation of women in Slovenia is worsening; out of 153 countries, Slovenia ranks 36th in closing the gender gap, which is a drop of -25 (World Economic Forum 2020). Economic vulnerability inevitably decreases women's ability to leave violent contexts and affects their health (Campbell 2002; Ramon 2015; Zaviršek 2015).

Nevertheless, there exist several important initiatives, campaigns and movements against gender-based violence in post-socialist countries. The famous antimilitarist feminist movement Women in Black, which was initiated in Serbia in the 1990s, addressed sexual violence as the weapon of war and helped women who were raped by solders during the war in Bosnia and Herzegovina to survive. In 2016, a Ukrainian feminist activist Nastya Melnychenko, having published her experience of rape on Facebook, instigated hundreds of women (and some men) in Ukraine and Russia to share their personal stories of sexual assault under the \#Yaneboyus'skazaty (\#I am not afraid to tell) hashtag. In the first two months, over 10,000 original posts were written in response, and over 16 million views were generated (Aripova, Johnson 2018: 488; Martsenyuk, Phillips 2020). In Croatia, 400 women testified about the torture inflicted on them by gynaecologists during childbirths in 2018, the campaign known as \#Stopthesilence- \#Prekinimošutnju (Matić 2018). The protest was triggered by a Member of Parliament Ivana Ninčević Lesandrić who, during a parliamentary session, publicly described how her hands and legs were strapped to the operating table while she was given the uterine abrasion without anaesthesia in a major hospital in Split. In a few days, hundreds of women reported similar stories and called them the 'medieval treatment' in hospitals (Tvig 2019). The torture during gynaecological treatments left women numbed, traumatised and silenced for years. The problem was recognised by the Higher Commissioner for Human Rights of the United Nations, who urged the Croatian government to stop violations of sexual and reproductive rights of women in Croatia (Bajruši 2019). 
Because of social media, many of these campaigns became internationally known and have had a profound impact on women in other countries, including Slovenia. These virtual campaigns show the importance of international influences of grassroots feminist activism, and they provide a differentiated picture of women's gender awareness in contrast to 1991.

\section{The \#metoo campaign in Slovenia}

In Slovenia, the \#metoo (\#jaztudi) campaign was initiated by four women public intellectuals, the author of this article being one of them. On 19 February 2018 we published an invitation addressed to women to disclose personal experiences of sexual assaults in different life situations under the hashtag \#jaztudi ${ }^{1}$ (Šumi et al. 2018). The $8^{\text {th }}$ March Institute (Inštitut 8. marec) took over the managing of the website where the stories were published. Most of the stories were anonymous without the names of the perpetrators ${ }^{2}$. When names appeared, we erased them, but informed the women on-line, where they could seek support or report the incidences of abuse. From February 2018 to the January 2020, over 200 testimonies were submitted mostly by women and published on the website. Many wrote more than one story. A few men wrote about their experiences of sexual harassment (by a female university professor and by a female friend). One transsexual person wrote about sexual assault by a heterosexual person.

The majority of those who responded were ordinary women with no intention to publicly disclose either a well-known or anonymous perpetrator, much less themselves. The stories could be described as 'ordinary', 'small' stories, far from spectacular testimonies: the narratives of everyday sexual assaults in childhood, during their teen years, and in adulthood. Women expressed no intention to blame, shame or prosecute the perpetrators. In many stories, women emphasised that they wrote down what they never told anyone before. There was an explicit or sometimes unspwoken desire and need to disclose what they went through for themselves and for others. They seemed to feel safe by remaining anonymous. The stories unveiled very personal narratives of everyday experiences of childhood sexual abuse at home, at school, in the church, in coffee shops, at parties and in the workplace, as well as in intimate partnerships, where sexual violence often came with physical violence. The perpetrators were from different social classes, professions and living either close to the victim, or were from far away. They were fathers, step-fathers and mother's partners, family friends, sport teachers, driving school instructors, priests, university professors, taxi and bus drivers, doctors, physiotherapists, unknown men in public places,

\footnotetext{
${ }^{1}$ Testimonies analysed in this article are published on the website jaztudi.si (it is still an ongoing project). They are translated into English by Petra Meterc and Maikes Kores.

${ }^{2}$ It was agreed that the stories contributed are open access public property. The website managers edited out the names of the perpetrators, as they were unable to take legal responsibility for disclosure.
} 
on local buses, in libraries, peers at schools, at parties, and after parties, unknown gangs of men.

The locations were arbitrary and showed that sexual assaults happen everywhere: in a stairwell, in grocery shop, in dark streets, in offices and ambulances, in buses and private rooms, in public toilets, at schools and universities. Sexual violence happened in presumably safe spaces of educational, health and pastoral institutions, as much as in spaces about which women already internalised the message that they were where 'they should expect' to be violated (in the secluded spots of cities and towns, in parks). Some women described their experiences of severe gang rapes. A young woman, who was repeatedly raped and wounded by three men, one of them a taxi driver, concluded her detailed description of the events: 'I wrote the story because I cannot tell it; I remember every detail six years later.'

As an indication of normalised violence, the word 'naïve' was as common as 'guilt', 'shame', 'frozen all over' and 'disgusted'. Women blamed themselves for being 'too naïve to recognise the danger' at the age of six, twelve, twentyfive. Some women described how they drank with some men and how someone drugged their drinks that rendered them unconscious, and how they woke up having been raped. They blamed themselves for their behaviour, for not having the proper knowledge from childhood about rape and abuse; they tell how they felt left alone with feelings of being dirty, polluted and ashamed. Who tells us that we are responsible for 'not knowing' evil, for failing to recognise it early enough to avoid it, to run away, to scream? The women's stories are memoirs of mourning what was done to them and of how their lives changed afterwards:

When we came to the car, he pushed me inside and covered my mouth. I remember that it hurt a lot and that he was very violent. He kept telling me dirty words and threatened me. Before he came, he pulled it out and came all over me. As soon as I left the car, I threw up and then ran to my friends. I started pouring alcohol into my mouth. I was not capable of doing anything else. $\mathrm{He}$ also came back and acted like nothing happened. That was my first sex.

In most instances, the women's stories disclosed how powerless they felt, rarely angry, and how they did not defend themselves. Some of the narratives were much more than a story. They were chronological diaries that revealed a painful history of repeated sexual assault and harassment based on gender stereotypes, men's learned behaviours and society's expectations. Sexual assaults were not single events but repeated in different periods of women's lives. Many women described the repeated incidences of sexual violence as a 'necessary evil' or even a 'woman's destiny':

It all started in my primary school. The classic ass grabbing from schoolmates. Even though I stood up for myself, got into a fight, slapped someone, they never stopped. Why? It's not a big deal, everyone does it. Then my first crush, my first kiss. Unfortunately, it didn't stop there, but I was too weak to resist him. He pushed me against a wall. He covered my mouth with one hand and with the other helped himself, as he said, to my sweet parts. As if 
I would be on a damn menu. I was 14 . I met him again about 5 years later, when he said that he was sorry. A few years later, it went all the way, unfortunately. He was a stranger; he was drunk.

Many stories described the experiences of childhood sexual abuse during which girls were disciplined to be friendly and compliant to men:

When I was a child, my father would often touch my breasts, as if to say 'let's see if they've grown,' even though I often expressed being uncomfortable (and resisted as well), he only laughed at me and always said that he is only 'joking.' Once when some family friends were visiting, he told me 'to show my titties' and I became very uncomfortable. He added 'if you won't show your titties, no boy will ever want you.'

Sexual assault in childhood is in a patriarchal order often seen as a rite of passage, a girl's introduction to womanhood. Girls are rarely told that they should refuse to be touched or kissed by an adult. Some were explicitly forbidden to say no to an overly kind uncle, grandfather, family friend, neighbour, or a 'friendly' stranger: 'When I was in high school, a priest "patted" me on the butt. I was so shocked that all I did was laugh.' Some women described how they internalised the responsibility for sexual violence they experienced as children and felt that they had to stay silent about it to protect the family from the bitter truth.

In rural environments in Slovenia, patriarchal attitudes towards children often couple with conservative Catholicism that speaks in favour of children's unquestioned obedience to parents, and acceptance of corporal punishment as part of everyday pedagogy (Zaviršek 2016). The victims spoke up only when their parents died, so as not to disappoint or hurt them by the disclosure of sexual violence at the hands of a priest (Zaviršek 2018). In one of the trials against a priest accused of sexual violence, the court delivered the not guilty verdict as it was 'not possible to prove that his violent sexual behaviour towards the girls would bring him sexual satisfaction' (Nimi 2011; Mekina 2018). The court case was initiated after four girls testified that the priest often touched their intimate body parts during religious and singing lessons in the church and in the car when he drove them home. The trial that took place in 2009-2011 is a memorable case of the court's misunderstanding of the nature of sexual assault and society's silent acceptance and normalisation of sexual violence against children. These stories are quite common in rural areas (Sandberg 2013). There is enough context to conclude that many women who wrote for the campaign were from rural parts of the country and from lower middle- or working-class households.

A related topic is the behaviour of teaching personnel in schools and other institutions that are seen primarily in their protective and caring role for the children and young people, but who often normalise sexual assault. 'Boys will be boys!' is a well-known phrase which naturalises and diminishes sexual abuse resulting in victims being unprotected and alone:

Our geography teacher in high school had a weird habit of walking between the benches and caressing girls during class. That is why the girls agreed 
with the boys that we will sit in the inner side of the benches and the boys took the outer side. But it didn't help. The teacher made his way there and stroked our arms and necks or rubbed against us.

It shows the low level of gender-based violence awareness among teachers, an issue which was already discussed in relation to the national data presented by the Agency for the Fundamental Rights (2015). German philosopher Carolin Emcke (2019) emphasised that one cannot conclude sexual harassment or sexual violence from a single gesture, a word or a touch, but that 'thick description,' a notion coined by the philosopher Gilbert Ryle (1996), is needed to obtain a contextual picture of the gesture, the word or the touch. Conversely, thin description often misunderstands the dangerous encounter, singularises it and erases the often premediated oppressive and dangerous context. It leads to disbelief and minimalization ('it was only a touch,' 'it happened accidentally'). Similar minimalizations happen in religious institutions that organise 'mediation sessions' with perpetrators and parents of the victim. They also make sure that a predator priest is simply moved to another parish, as the church authorities are not obliged to report the case of sexual violence to police. In some cases, the Slovenian Catholic Church actively protected the accused, and in one case that was made notorious by the media the priest was sent as far as to Malawi (Zaviršek 2016).

Some testimonies described the grief and anger related to the mothers of girls who failed to 'see' and protect their daughters: 'all cries for help were not enough for my mother to protect me.' Do parents in neopatriarchal societies lack awareness of sexual abuse against children? Are denial, fear and powerlessness of the non-abusive parent so strong as to prevent recognition and speaking up? Some mothers are economically or emotionally dependent on the perpetrator, some are frozen in denial of their own experiences of sexual abuse, some are afraid, react with disbelief and blame the victim:

In his presence, I told my mother that he touched me, and asked her to tell him to stop. However, she remained silent and went away. This still hurts me until present days, although I am 30, more than the touching of her partner.

Consequently, the expectations are that girls and young women need to be 'ready' for all sorts of sexual offers and activities: 'With guilt, he managed to implement a feeling of duty in me.' Part of the neopatriarchal discipline in womanhood is the expectation that girls have to be ready for sexual activities at an early age: the stories show that the younger the girls, the more likely they become victims of sexual assault. A woman with severe long-term experiences of violent rapes and physical violence by gangs of men wrote: 'Sexual abuse keeps on happening to me because I am unable to defend myself, because they made me timid and I have the feeling that I don't have the right to defend myself.' Early disciplining in sexual violence turned the women into silent survivors. Almost everyone kept their perpetrator anonymous; their aim was not to make a public announcement against the violator, but to narrate the survived violence and how they coped after the experience. 
The stories showed that women who survived sexual assaults did everything to avoid the perpetrators. Some were afraid of them and some felt disgusted and wanted to make themselves unnoticed or even invisible. Some quit the jobs they needed to survive. Economic inequalities and gender discrimination experienced by women very much depend on harmful social norms like sexual assault:

There are several stories to tell... Each has its own weight and pain, but I'd like to focus on one in particular: I was in my first year of high school. I was a young, engaged and full of energy. Me and the other students who had to drive to school from other towns took afternoon classes. $<\ldots>$ The intercity bus was practically empty one morning around $11 \mathrm{a}$ a.m. People had kept getting off, I had had to drive to the terminal station. It was just the driver and me... He drove the bus to the very edge of the terminal... I wanted to get off, but the door remained closed. He got up... I don't remember much, just scratched skin on my left cheek, his dark brown beard, the ripped lining of my winter coat, and a burning pain on my thigh. I walked across town... I made it to the school but couldn't manage to climb the grey staircase. I cut class exactly once in four years... I never took the 11 a.m. intercity bus again.

Some stories revealed that the perpetrators were widely known for what they were doing but nobody moved to stop the cycle of sexual violence. In one story, a girl at the doctor's office was asked to come behind his desk and look at the computer where there was pornography. At that moment, the doors opened and a rescue worker entered the room: 'You are showing these kinds of things again, just stop it!', said the young man to the doctor while the girl used the moment to escape from the room. Both remained silent. It is a form of "initiation", one of the survivors wrote. Is this not precisely how neopatriarchy works? Not only men, but women as well expect other women to experience the same torture they underwent: 'I suffered; my daughter will suffer too.' There is lack of empathy and intention, not to mention courage, to stop violence; rather, the expectation is that such events are part of normal preparation for life as a woman.

Women who experienced sexual abuse and violence as children and adolescents were less able to protect themselves when they were adults: 'When it happened for the first time, I went numb with surprise. Because I was raped as a teenager, I was always afraid of violent men, even though they were only violent verbally.' Some stories revealed the complete powerlessness of young girls. These experiences marked them, left them traumatized and showed them where their place in the society was:

I have been touched inappropriately by men, both my age and older. The worst thing is when my boyfriend's uncle touches me, and my boyfriend doesn't see anything. I am 17 years old, and I'm embarrassed that the people close to me never notice what is happening.

The \#jaztudi campaign in Slovenia shows that women of all social classes and different ages feel the need to speak out about violence. Still, the structural 
and personal obstacles favour their silence and make sure that the perpetrators remain unknown and not responsible for what they did. Hence, some women expressed their uncertainty about writing what happened to them in the first place: 'I'm not sure if this story is for the \#metoo'; 'I have many stories but nobody is alarmed by them'; 'This is not a story which would shock anyone'. They restrict themselves even in the virtual public space where they can remain anonymous. They question the 'weight' of their experiences and are unsure whether they are 'real victims' or whether their experiences are 'heavy enough' to be told. Is this not a clear sign that many women see sexual assault as part of womanhood? They knew that there are 'more horrible stories' than theirs out there: 'My story is an ordinary story'; 'I didn't describe all examples of sexual harassment because other women will write much more horrible stories.' This is the situation of silencing. There is no doubt that the perpetrators, to recall the classical book of Judith Lewis Herman (1992), expect the victims to remain silent.

\section{Conclusions}

The analysis of the \#jaztudi campaign suggests that there are indeed local specificities in the Slovenian material. One of the major differences between this material and that which surfaced in certain Western countries is that in the \#jaztudi campaign, the women who experienced sexual violence are far from the point of taking legal actions against the perpetrators: 'Do I want to report the perpetrators? No, I wish that this would never happen.' This can partially be explained by the contexts of rurality, religious influences and the social norms related to sexual violence towards women that get reproduced in the educational, judicial and other social systems. In the rural context, it is even more difficult to reveal sexual violence, as those employed in the professional services (police, medical personal, social workers) know each other as well as the victim and the perpetrator. The high threshold of the taken-for-granted sexual violence against girls and women and the rare sentencing of the perpetrators prevented the women from disclosing their experiences of sexual assaults earlier. This effect is common for the situation of normalisation of gender-based violence in the conditions of neopatriarchy, especially intersecting with rurality and economic inequality. The \#metoo campaign appeared at the peak of the era of neopatriarchy where global inequalities are on the rise (Šumi, Zaviršek 2017).

Another important feature of the Slovenian \#metoo stories was that the women focused on sexual violence, sometimes with severe physical health consequences, not only on sexual harassment. Despite the gravity of violence, the episodes tended to be ignored and forgotten. The \#jaztudi campaign finally gave many women from post-socialist Slovenia the opportunity to create collective knowledge of sexual assaults against girls and women that did not gain publicity before and had never been condemned. When just one person remembers, the event can fall in oblivion: it becomes a non-event, to recall the 
classic work of Maurice Halbwachs (1992). Only when the collective remembers can events be memorised and give strength to those who are afraid and ashamed to testify about what they endured. This collective remembrance should now translate into protective social policy and law. Feminists and women who dare to share their experiences of violence are the crucial actors in the political struggle to implement the Council of Europe Convention on preventing and combating violence against women and domestic violence. The first step is to change national legislation, and then everyday practices.

\section{Acknowledgements}

The article is part of the research activities funded by the National Research Agency of the Republic of Slovenia.

\section{References}

Aripova F., Johnson J. E. (2018) The Ukrainian-Russian Virtual Flash Mob against Sexual Assault. The Journal of Social Policy Studies, 16 (3): 487-500.

Bajruši R. (2019) UN: Odmah prestanite kršiti reproduktivna prava žena. Jutranji list. Available at: https://clck.ru/NBQni (accessed 20_February 2020).

Campbell B. (2015) Ending the Neoliberal Neopatriarchy. Institute of Art and Ideas News, (27). Available at: https://clck.ru/NQdCj (accessed 8 May 2020).

Campbell J. C. (2002) Health Consequences of Intimate Partner Violence. Lancet, (359): 1331-1336. Emcke C. (2019) Ja heist ja und... Frankfurt a. Main: S. Fischer.

EU Agency for Fundamental Rights (2015) Violence against Women: An EU-wide Survey. Available at: https://clck.ru/NBQtc (accessed 23 February 2020).

Fábián K. (2010) Introduction: The Politics of Domestic Violence in Postcommunist Europe and Eurasia. In: K. Fábián (ed.) Domestic Violence in Postcommunist States. Local Activism, National Policies and Global Forces. Bloomington: Indiana University Press: 1-44.

Funk N. (2014) A Very Tangled Knot: Official State Socialist Women's Organizations, Women's Agency and Feminism in Eastern European State Socialism. European Journal of Women's Studies, 21 (4):344-360.

G.C. (2019) Plačna vrzel med spoloma v EU-ju najbolj narašča v Sloveniji. MMC RTV SLO. Available at: https://clck.ru/NBQyD (accessed 23 February 2020).

Globevnik Velikonja V. (2018) Nasilje nad ženskami in reproduktivno obdobje. In: R P. Jelenko (ed.) Duševno zdravje v obporodnem obdobju. Available at: https://clck.ru/NBQzx (accessed 23 February 2020).

Gradskova Y., Kondakov A, Shevtsova M. (2020) Postsocialist Revolutions of Intimacy: An Introduction. Sexuality \& Culture, (24): 359-370.

Haan F. de, Daskalova K., Loutfi A. (eds.) (2006) Dictionary of Women's Movement and Feminisms. Central, Eastern, and South Eastern Europe, 19th and 20th Centuries. Budapest: CEU Press.

Haan F. de (2016) Ten Years After. Communism and Feminism Revisited. Aspasia, 10 (1): 102-168. Herman J. (1992) Trauma and Recovery: From Domestic Abuse to Political Terror. New York: Basic Books.

Halbwachs M. (1992) On Collective Memory. Chicago: University of Chicago Press. Jalušič V. (2002) Kako smo hodile v feministično gimnazijo. Ljubljana: Založba.

Kovač N., Šumi I., Zaviršek D., Šribar R. (2018) \#jaztudi Slovenija. Delo, Sobotna Priloga, 2 March. Available at: https://clck.ru/NQdKJ (accessed 23 February 2020). 
Kuhar R., Paternotte D. (2017) Anti-Gender Campaigns in Europe. Mobilizing Against Equality. London: Rowman and Littlefield.

Leskošek V., Urek M., Zaviršek D. (2010) Poročilo o nacionalni raziskavi o nasilju nad ženskami v zasebni sferi in v partnerskih odnosih. Available at: https://clck.ru/NBR5L (accessed 23 February 2020).

Lukić J., Regulska J., Zaviršek D. (eds.) (2006) Women and Citizenship in Central and Eastern Europe. Farnham: Ashgate.

Martsenyuk T., Phillips S.D. (2020) Talking About Sexual Violence in Post-Maidan Ukraine: Analysis of the Online Campaign \#IAmNotAfraidToSayIt. Sexuality \& Culture, (24): 408-427.

Matić Ž. (2018) Zakaj ženske na Hrvaškem po nepotrebnem trpijo. Delo. Available at: https:// clck.ru/NBREh (accessed 23 February 2020).

Mekina B. (2018) Pokvarjeni moralni kompas. Mladina. Available at: https://clck.ru/NBRGd (accessed 23 February 2020).

Nimi (2011) Župnika oprostili obtožb. Turistično društvo Polenšak. Available at: https://clck. ru/NBRJD (accessed 23 February 2020).

Pilkington E. (2020) Weinstein Team to Allude to Emails with Accusers in Presentation to Jury. The Guardian. Available at: https://clck.ru/Lybue (accessed 8 May 2020).

Ramon S. (2015) Intersectionalities: Intimate Partner Domestic Violence and Mental Health Within the European Context. Intersectionalities, 4 (2): 76-100.

Ryle G. (1996) The Thinking of Thoughts: What is 'Le Penseur' Doing? Available at: https:// clck.ru/NBRVr_accessed 23 February 2020).

Robnik S. (2010) Domestic Violence against Women: When Practice Creates Legislation in Slovenia. In: K. Fábián (ed.) Domestic Violence in Postcommunist States. Local Activism, National Policies and Global Forces. Bloomington: Indiana University Press: 195-218.

Report from the Region (2019) The 'Anti-Gender' Wave Contested: Gender Studies, Civil Society, and the State in Eastern Europe and Beyond. Aspasia, 13 (1): 1-11.

Runarsdottir E., Smith E., Arnarsson A. (2019) The Effects of Gender and Family Wealth on Sexual Abuse of Adolescents. International Journal of Environmental Research and Public Health. Available at: https://clck.ru/NQdS9 (accessed 8 May 2020).

Sandberg L. (2013) Backward, Dumb, and Violent Hillbillies? Rural Geographies and Intersectional Studies on Intimate Partner Violence. Affilia, 28 (4): 350-365.

Sharabi H. (1988) Neopatriarchy. A Theory of Distorted Change in Arab Society. Oxford: Oxford University Press.

Statistical Office of the Republic of Slovenia (2020) SDG Indicators. Available at: https://clck. ru/NBRdp (accessed 23 February 2020).

Šumi I., Zaviršek D. (2017) Ženska v krasnem novem neoliberalnem svetu. Delo, Sobotna priloga, (4): 8-9.

Tvig K. (2019) 'Bio je kasapin': Žene u Hrvatskoj ustale protiv zlostavljanja na porođaju. BBC Zagreb. Available at: https://clck.ru/NBRhi (accessed 23 February 2020).

WAVE (2014) Women Against Violence Europe. Country Report. Vienna: WAVE.

World Economic Forum (2020) Global Results. Available at: https://clck.ru/NBRjE (accessed 23 February 2020).

Zaviršek D. (1997) Diskurzi nasilja in pomoči. Socialno delo, 36 (5-6):329-346.

Zaviršek D. (2015) Between Care and Violence: Disabled Women's Experiences of Violence. In: K. Jagielska, J. M. Łukasik, N. G. Pikuła (eds.) Violence Against the Elderly-ChallengesResearch-Action. Toronto: Nova:47-64.

Zaviršek D. (2016) Doktrina in metode socialnega dela na področju podpore žrtvam spolnih zlorab v katoliški cerkvi. Socialno delo, 55 (1-2): 7-25.

Zaviršek D. (2018) Skrb kot nasilje. Ljubljana: Založba.

Zaviršek D., Rajgelj B. (2018) Anti-Refugee Sentiment without Refugees: Human Rights Violations and Social Work in Post-Socialist Countries of Southeastern Europe in their Social Contexts. Journal of Human Rights and Social Work, (4) 1: 5-16.

Zaviršek D., Sobočan A. M. (eds.) (2012) Mavrične družine grejo v šolo: perspective otrok, staršev in učiteljic. Ljubljana: Fakulteta za socialno delo. 